\title{
Comparative hydrodynamics of a sub-tropical salt-wedge estuary and a tributary
}

\author{
Mariana Afonso Abade Couceiro ${ }^{1, *(0)}$, Carlos Augusto França Schettini2 ${ }^{(1)}$
}

\author{
1 Instituto Oceanográfico, Universidade de São Paulo, (Praça do Oceanográfico - 191 - Butantã - 05508-120 - São Paulo - SP - Brazil) \\ ${ }^{2}$ Instituto de Oceanografia, Universidade Federal do Rio Grande, (Avenida Itália - km 8 - $96201-900$ - Rio Grande - RS - Brazil) \\ * Corresponding author: mariana.abade@gmail.com
}

\section{Abstract}

The objective of this study is to compare the physical characteristics of circulation, salinity structure and transport in the Itajaí-Açu and Itajaí-Mirim estuaries. Due to its importance, the Itajaí-Açu estuary has been studied in the last decade. However, its main tributary, the Itajaí-Mirim has never been assessed, especially as an opportunity to comparatively investigate the flow behavior of salt wedge estuaries with different widths and depths. Field data were acquired during two campaigns that covered the complete semi-diurnal tidal regimes during spring and neap tides. Water level, total transport volume, current and salinity were recorded hourly and synoptically at cross-sections in each estuary. The campaigns were conducted during a prolonged period of low river discharge. The tidal range during the spring and neap tide campaigns were of approximately 1.2 and $0.4 \mathrm{~m}$, respectively. At the Itajaí-Açu and Itajaí-Mirim cross-sections, the peak ebb and flood currents were -0.8 and $-0.6 \mathrm{~m} \mathrm{~s}^{-1}$ and 0.8 and $0.4 \mathrm{~m} \mathrm{~s}^{-1}$, respectively, during the spring tide campaign, and classified as well mixed and highly stratified estuaries, respectively. During the neap tide campaign, both estuaries were classified as salt wedge. The dominant mechanism was the salt transport by advection due to fluvial advection in both estuaries and campaigns. The landwards salt transport, which resulted from dispersive processes, was only important during neap tide for the Itajaí-Açu estuary.

Descriptors: Itajaí-Mirim, Itajaí-Açu, advective salt transport, estuarine circulation.

\section{INTRODUCTION}

Several large coastal cities have spread along estuarine margins. Land use and development was initially based on favorable country access conditions, which allowed for the construction of harbors and trade centers for the fishing and shipyard industries. In contrast, estuaries are sensible environments and very important pathways for the mass flux of materials from continents towards the ocean. Estuaries are very important environments for primary productivity

Submitted: 04-Dec-2020

Approved: 14-Jun-2021

Associate Editor: Cesar Rocha

() 2021 The authors. This is an open access article distributed under the terms of the Creative Commons license. because they receive the direct continental supply of nutrients. Salt marshes or mangrove forests are common features along estuarine margins and function as habitats for birds, mammals and fish. In addition, these areas are important nurseries for commercial fish species. Unplanned estuary occupation, the inflow of agricultural, domestic and industrial effluents, and the lack of estuary management endanger the sustainable development of these environments.

Estuaries are defined as a semi-enclosed water bodies with a free connection to the open sea, where the seawater is measurably diluted by fresh water from the drainage basin (Cameron and Pritchard, 1963). Tides play an important role in estuaries because they provide the energy to produce mixing of fresh and salt waters (Geyer and MacCready, 2014). 
Estuaries can be divided into the following sectors according to salinity: (1) the lower estuary with a free connection to the sea, (2) the middle estuary where mixing between fresh and salt water occurs, and (3) the upper estuary with tidal effects but no salinity (Dionne, 1963). Although the density difference between fresh and salt water $(\sim 2 \%)$ is relatively small, this difference is important due to the spatial and temporal scales of the dynamic processes that drive estuarine circulation (Dyer, 1997; Miranda et al., 2012; Geyer and MacCready, 2014). The complex interactions among river discharge, tides and morphology produces distinct salinity distribution patterns that are (1) highly stratified, (2) partially mixed or (3) well mixed. The identification and classification of the salinity structure of a given estuary is useful to infer the main driving forces that act on the system and the transfer mechanisms, which varies greatly as function of the circulation.

Dozens of small estuaries occur along the Santa Catarina coastline, Southern Brazil. These systems are mainly river dominated ones that have a salt-wedge salinity structure (Schettini et al., 1996, Schettini and Carvalho, 1998; Schettini et al., 2006, D'Aquino et al., 2010, 2011a, 2011b; Barreto and Schettini, 2014; Valle-Levinson et al., 2016) although some can also exhibit a partially mixed structure (Schettini and Carvalho, 1999, Schettini, 2002a, Franklin-Silva and Schettini, 2003; Siegle et al., 2009). The Itajaí-Açu estuary is the largest and received more attention due to harbor activity along its lower stretch. The sedimentology and hydrodynamics of the Itajaí-Açu estuary were assessed by Döbereiner (1986), Ponçano and Gimenez (1987), Schettini and Carvalho (1998), Schettini $(2002 a, b)$, Schettini and Toldo Jr (2006) and Schettini et al. (2006). The Itajaí-Mirim estuary debouches in the Itajaí-Açu estuary $7 \mathrm{~km}$ from the mouth, being its main tributary in the estuarine area, accounting for about $10 \%$ of the freshwater inflow. Previous assessment on the Itajaí-Mirim showed that it also has a salt-wedge salinity distribution, therefore it is shallower and narrower than the Itajaí-Açu. The objective of this paper is to compare the hydrodynamics of the Itajaí-Açu and Itajaí-Mirim estuaries synoptically, based on a field experiment to obtain a description of the highly stratified flow regime under the same tidal and hydrological conditions.

\section{METHODS}

\section{Physical setting}

The Itajaí-Açu estuary is located on the northern coast of Santa Catarina State and is nearly 80 $\mathrm{km}$ from the Florianópolis State Capital. It's inlet is at $26^{\circ} 54^{\prime} \mathrm{S}$ and $48^{\circ} 38^{\prime} \mathrm{W}$ (Figure 1). The total drainage basin is $15,500 \mathrm{~km}^{2}$, with nearly $14,100 \mathrm{~km}^{2}$ for the Itajaí-Açu River and $1,400 \mathrm{~km}^{2}$ for the Itajaí-Mirim River. The regional climate is mesothermic wet (or humid subtropical according to the Köppen-Geiger climate classification) with rainfall throughout the year. The mean precipitation rate is $1,415 \mathrm{~mm} \mathrm{yr}^{-1}$, and the mean evapotranspiration rate is $1,080 \mathrm{~mm}$ $\mathrm{yr}^{-1}$ (Gaplan, 1986). The mean monthly temperature is $20.3{ }^{\circ} \mathrm{C}$, with a maximum of $25.2^{\circ} \mathrm{C}$ in January or February and a minimum of $16.5^{\circ} \mathrm{C}$ in July (Araújo et al., 2006). The significance of the sub-tropical climate is reflected on the lack of a seasonal pattern. Episodes of high river flow lasting a few days or of longer periods (> 1 month) of low river flow can happen at any time of the year (Schettini, 2002).

The Itajaí-Mirim River flows into the Itajaí-Açu estuary $7 \mathrm{~km}$ upstream of the ocean inlet. The geometry of both estuaries is very regular, and resembles meandering rivers with a nearly constant width. The Itajaí-Açu River is approximately $200 \mathrm{~m}$ wide, and the Itajaí-Mirim River is approximately $40 \mathrm{~m}$ wide. The main difference between the two rivers is that the Itajaí-Mirim River is an artificial channel that was built during the 1960s to minimize flooding in its basin. Thus, the Itajaí-Mirim River is less than $8 \mathrm{~km}$ long. The mean depth of the Itajaí-Mirim is approximately $4 \mathrm{~m}$. The natural river course was abandoned in favor of the channel. The Itajaí-Açu bathymetry indicated an average depth of $7 \mathrm{~m}$ with boreholes of more than 10 $\mathrm{m}$. In addition, the lower $4 \mathrm{~km}$ of the Itajaí-Açu River is continuously dredged to $11 \mathrm{~m}$.

River discharge from both drainages has been monitored daily since 1929 by the Brazilian National Water Agency. The mean river discharge of the ItajaíAçu was $230 \mathrm{~m}^{3} \mathrm{~s}^{-1}$ when measured $90 \mathrm{~km}$ from its mouth (Schettini, 2002a). In addition, the mean river discharge from the Itajaí-Mirim was $32 \mathrm{~m}^{3} \mathrm{~s}^{-1}$ when measured $30 \mathrm{~km}$ from its mouth. Both drainages have short concentration times that cause great temporal variability in river discharge in addition to the 


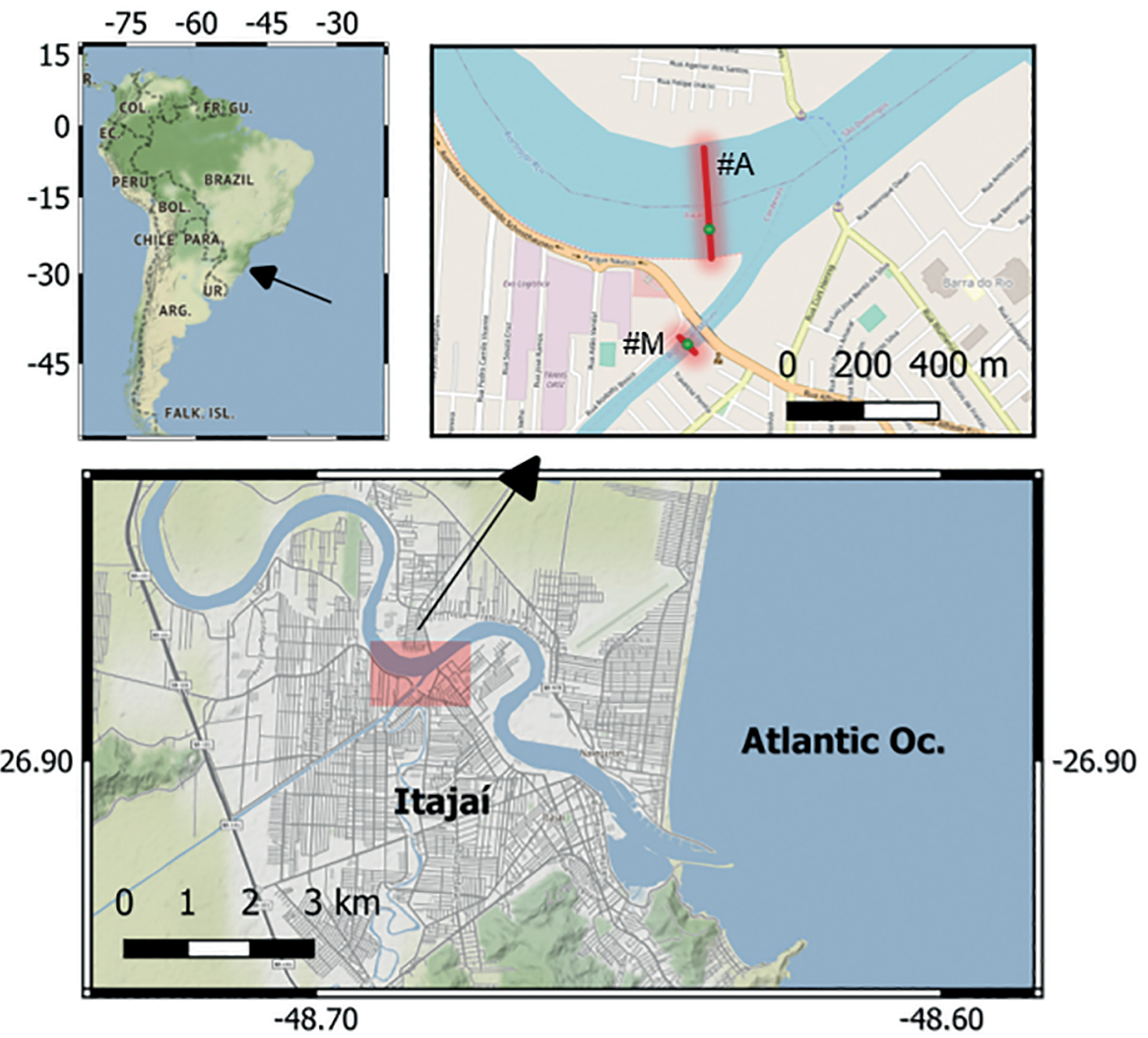

Figure 1. Location of the Itajaí-Açu and Itajaí-Mirim estuaries in South America with cross-sections (red lines) of \#A and \#M, respectively. The green circles indicate the positions of the CTD sampling stations.

well-distributed rainfall. The discharge is generally low with randomly distributed peak discharges that are one order of magnitude higher (Schettini, 2002a).

The regional tide consists of mixed semi-diurnal microtides that range in height from 0.3 to $1.2 \mathrm{~m}$ during the neap and spring tides, respectively. The form number, which is the ratio of the sum of the two main diurnal tidal constituents $(\mathrm{O} 1+\mathrm{K} 1)$ to the sum of the two main semi-diurnal constituents (M2 + S2) (Pond and Pickard, 1983), is 0.4 (Schettini, 2002a). This form number indicates that the differences between the successive high tides and low tides are noticeable. In addition, the local quarti-diurnal overtides and compound tides are the same order of magnitude as the principle astronomical diurnal constituents. This relationship results in a complex tidal signal during the neap tide, when four periods of high water and four periods of low water are observed each day (Schettini, 2002a).

The Itajaí-Açu River results in stratified estuarine circulation with frequent salt wedge salt intrusion behaviors (Schettini, 2002a; Schettini et al., 2006). Salt intrusion can occur as far as $30 \mathrm{~km}$ up the estuary during low river discharge periods. Meanwhile, all saline water is flushed out when the river discharge exceeds $1,000 \mathrm{~m}^{3} \mathrm{~s}^{-1}$. Schettini (2002a) suggested that the Itajaí-Açu lower estuary (Dionne, 1963), which often has greater marine water content, extends $7 \mathrm{~km}$ upstream from its mouth and to the mouth of the Itajaí-Mirim. However, the Itajaí-Mirim estuary tidal effects are also subject to the marine waters.

\section{FieLd Surveys}

Tidal surveys were conducted on August 26th and September 2nd in 2003 during spring and neap tide conditions, respectively. The Itajaí-Mirim experimental cross-section (\#M) was situated near the estuary mouth and $300 \mathrm{~m}$ away from the Itajaí-Açu experimental crosssection (\#A). The Itajaí-Açu experimental cross-section was situated landwards of the Itajaí-Mirim confluence on the Itajaí-Açu channel. The Itajaí-Açu cross-section was approximately $7 \mathrm{~km}$ from its mouth (Figure 1). 
Due to the proximity of the cross-sections, they were surveyed by the same team on nearly a synoptic scale. Water elevation, total volume transport, current and salinity were sampled hourly over 14 hours. Water elevation was recorded at 0.5-hour intervals with a pressure gauge moored at the margin of \#M. Total volume transport was recorded with an Acoustic Döppler Current Profiler (ADCP) by Sontek model ADP-1500 with a bottom track. The ADCP setup used an average sample time of $5 \mathrm{~s}$ at $2 \mathrm{~Hz}$ and a cell size of $0.25 \mathrm{~m}$. Considering the cross section widths, volume transport was averaged for 30 and 8 vertical current profiles at \#A and \#M, respectively. For each current measurement, the boat navigated from one margin to another, returning to the thalweg to conduct the vertical salinity and temperature profiles. The vertical salinity and temperature profiles were recorded with a CTD probe by Saiv, A/S model SD204 operating at $1 \mathrm{~Hz}$.

Single vertical current speed and direction profiles were extracted from each ADCP cross-section measurement. Five vertical profiles were selected that were centered on the thalweg area and were nearly in the same locations as the CTD profiles. Due to varying depth, the possible variations across the profile lengths were adjusted linearly to the mean depth of all profiles. Thus, the resulting vertical current profiles were averaged over $25 \mathrm{~s}$ to reduce the noisy signal caused by turbulence. A convention for assigning positive values to upstream current floods and negative values to current ebbs was adopted. The vertical currents and CTD data were re-sampled to produce nine equivalent vertical observations between $1 \mathrm{~m}$ below the surface and $1 \mathrm{~m}$ above the bed. All data were adjusted according to the water level variations and mean local depth. Vertical and temporal current and salinity distribution diagrams were constructed from the resulting regular matrix of data (9 vertical levels $x 14$ temporal) and adjusted according to the temporal water depth variations.

The water column stability during the tidal cycles was investigated using the layer Richardson number $\left(R i_{L}\right)$ which compares the effects of the density gradient and shear-induced turbulence. It is defined as:

$$
R_{i L}=\frac{g h \Delta \rho v}{\rho \bar{u}^{2}},
$$

where $g\left(\mathrm{~m} \mathrm{~s}^{-2}\right)$ is the gravity, $h(\mathrm{~m})$ is the depth, $\Delta \rho_{v}\left(\mathrm{~kg} \mathrm{~m}^{-3}\right)$ is the difference between surface and bottom density, $\rho\left(\mathrm{kg} \mathrm{m}^{-3}\right)$ is the averaged density, $\mathrm{u}(\mathrm{m}$ $\mathrm{s}^{-1}$ ) is the longitudinal velocity component. According to Dyer and New (1986), the physical interpretation of the layer Richardson number is: for $R i_{L}>20$ the water column is highly stable; when $R i_{L}<20$ the bottom turbulence increases, and the stratification decrease; if $R i_{L}<2$ the turbulent mixing makes the water column unstable and mixing is fully developed.

The estuaries were classified according to the stratification diagram and circulation proposed by Hansen and Rattray (1966) and detailed in Miranda et al. (2012), and by Geyer and MacCready (2014). The Hansen and Ratrray (1966) classifications is anchored in two hydrodynamics non-dimensional parameters: (a) the circulation parameter: calculated as the ratio of the time averaged surface velocity to the time and depth-averaged velocity $\left(\left\langle U_{s}\right\rangle /\langle\bar{U}\rangle\right)$, and (b) the stratification parameters: calculated from the time averaged vertical profile as the ratio of the difference between the bottom and surface salinity to the vertical mean salinity $\left(\left\langle S_{B}-S_{s}\right\rangle /\langle\bar{S}\rangle\right)$. The Geyer and MacCready (2014) estuarine parameter space is based on the principal forcing variables, the fluvial Froude number $\left(F r_{f}\right)$ and the mixing parameter $(M)$, with appropriate nondimensionalization. Freshwater Froude number was calculated as $F r_{f}=U_{r} / N_{o}$, where $U_{r}$ is the velocity due to river flow (the river volume flux divided by river cross section area), and mixing number as $M=\left(C_{d} U_{t}^{2} / \omega N_{o} H^{2}\right)^{1 / 2}$, where $U_{t}$ is the amplitude of the depth-averaged tidal velocity, and $\mathrm{No}=$ $\left(\beta_{\text {ocean }} H\right)^{1 / 2}$ is the buoyancy frequency for maximum top-to-bottom salinity variation in an estuary.

The advective transport of salt was computed according to the procedure described by Miranda et al. (2012) and based on the developments of Bowden (1963), Fischer (1976), Hunkins (1981), Dyer (1974) and Kjerfve (1986). The advective transport of salt occurs from the decomposition of baroclinic and barotropic circulation effects in a laterally homogeneous cross-section. Values and measurements of velocity $U$ $(x, z, t)$ or salinity $S(x, z, t)$ can be considered as the sum of an averaged value $U_{a}(x)$, the barotropic $U_{t}(x, t)$ baroclinic $\mathrm{U}_{\mathrm{z}}(x, z)$ and residual, $\mathrm{u}^{\prime}(x, z, t)$.

The total salt mass transport per unit of width was calculated as follows: 


$$
\mathrm{T}_{s}=\frac{1}{T} \int_{0}^{T} \int_{0}^{\mathrm{h}} \rho U S \mathrm{dzdt},
$$

where $T$ is the period of one tidal cycle and $\rho$ is the water density. In addition, the water depth varies along the tidal cycle, and can be decomposed as an average depth plus its variation $D(x, t)=D_{a}(x)+$ $z(x, t)$. By substituting the velocity $U$ by the sum of the decomposed terms $U_{a}+U_{t}+U_{z}+u^{\prime}$, the salinity $S$ by $S_{a}$ $+S_{t}+S_{z}+s^{\prime}$, and by $D_{a}+z, 32$ terms were obtained. Most of these terms are null with no physical meaning. The remaining seven terms are as follows:

$$
\begin{aligned}
& T_{s}=\bar{\rho}\left(u_{a} h_{a} S_{a}+\left\langle h_{t} u_{t}\right\rangle S_{a}+h_{a}\left\langle u_{t} S_{t}\right\rangle\right. \\
& \left.+h_{a} \overline{u_{s} S_{s}}+h_{a}\left\langle\overline{u^{\prime} s^{\prime}}\right\rangle+\left\langle u_{t} S_{t} h_{t}\right\rangle+u_{a}\left\langle S_{t} h_{t}\right\rangle\right)
\end{aligned}
$$

The brackets denote time averaging, and the over bars denote depth averaging. The seven terms on the right side of the Eq. 3 are attributed to (1) fluvial advection, (2) Stokes drift, (3) tidal correlation, (4) gravitational circulation, (5) tidal pumping, (6) tidal shear and (7) long term fluctuations.

\section{RESULTS}

\section{Spring Tide Campaign}

The water level variations and instantaneous volume transport for the \#A and \#M cross-sections along the spring tide campaign are presented in Figure 2. The water level indicated low water (L.W.) at 08:30 $\mathrm{h}$ and 21:00 $\mathrm{h}$ and high water (H.W.) at 15:30 h. The volume transport in both cross-sections showed a clear tidal signal that was related to sea level. The extreme values at \#A were approximately $800 \mathrm{~m}^{3} \mathrm{~s}^{-1}$ and the extreme values at \#M were approximately 75 $\mathrm{m}^{3} \mathrm{~s}^{-1}$. The extreme discharge at \#M occurred earlier than the extreme discharge at \#A, and continued for approximately one hour during flood flow and two hours during ebb flow. The maximum flood discharges occurred at 11:30 $\mathrm{h}$ and 12:30 $\mathrm{h}$ at \#M and \#A, respectively. The maximum ebb discharges occurred at 16:30 $\mathrm{h}$ and 18:30 $\mathrm{h}$ at $\# \mathrm{M}$ and $\# \mathrm{~A}$, respectively.

Current velocities at \#A were approximately \pm 0.8 $\mathrm{m} \mathrm{s}^{-1}$, were symmetric near the surface in both cases and were smaller near the bottom (Fig. 3). The current direction reversal from ebb to flood occurred at 09:00 h, nearly 0.5 hour after L.W. The current reversal from flood to ebb occurred at 15:30 h, two hours after H.W. The current velocities at \#M were asymmetric and varied from 0.4 to $-0.6 \mathrm{~m} \mathrm{~s}^{-1}$ during the flood and ebb periods, respectively. The current direction reversal from ebb to flood occurred at 08:30 $\mathrm{h}$ during L.W. The flood to ebb current reversal occurred at 14:30 $\mathrm{h}$ and nearly one hour after the H.W.

The vertical salinity distribution at \#A was generally homogeneous with greater stratification after 13:00 $\mathrm{h}$ and following H.W (Fig. 3). The temporal salinity variations ranged from 20 to $30 \mathrm{~g} \mathrm{~kg}^{-1}$. Greater salinity values were observed during the late flood stage. At \#M, the vertical distribution of salinity was more stratified. Thus, the water column becomes well mixed during the flood period. The salinity varied temporally from less than $10 \mathrm{~g} \mathrm{~kg}^{-1}$ to more than 30 $\mathrm{g} \mathrm{kg}^{-1}$. Smaller salinity values were observed at L.W. in the beginning of the campaign at the surface and higher values were observed at H.W. at the bottom.

\section{Neap Tide Campaign}

The water level variations and instantaneous volume transport for the cross- sections of \#A and \#M along the neap tide campaign are presented in Figure 2. The water level variations included two H.W. and two L.W. events during the campaign. This complex pattern of water level variations in relation to the spring tide is potentially related to the quartidiurnal tide (Schettini, 2002a). The dominance of the semi-diurnal tide is observed for the first four hours by the oscillation of greater magnitude. The high water events occurred at 07:30, 12:00 and 19:00 hours and the low water events occurred at 10:00 and 16:00 hours. The volume transport in the \#A cross-sections agreed with the water level regime and reached a maximum ebb of approximately $-600 \mathrm{~m}^{3} \mathrm{~s}^{-1}$ and a maximum flood of approximately $130 \mathrm{~m}^{3} \mathrm{~s}^{-1}$. The volumes transported in the \#M cross-section were approximately $40 \mathrm{~m}^{3} \mathrm{~s}^{-1}$ during flood conditions and -70 $\mathrm{m}^{3} \mathrm{~s}^{-1}$ during ebb conditions.

Figure 4 shows the temporal and vertical velocity and salinity distributions at \#A and \#M. At the beginning of the campaign, in the \#A cross-sections, a pronounced current ebb was observed of approximately $-0.6 \mathrm{~m} \mathrm{~s}^{-1}$ near the surface that decreased with depth. The current velocity data show a pattern of reverse currents from 13:00 $\mathrm{h}$ with downstream current directions for the first $4 \mathrm{~m}$ and upstream current directions 

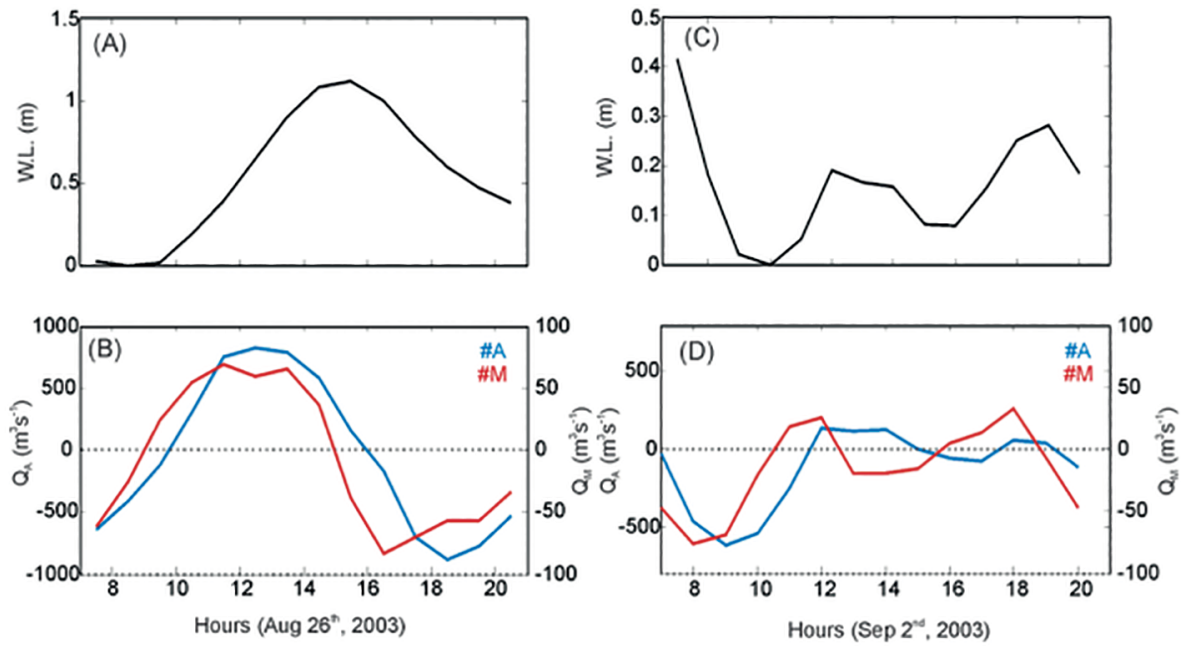

Figure 2. Hourly variations of water level (A) and volume transport $\left(\mathrm{m}^{3} \mathrm{~s}^{-1}\right)$ across the Itajaí-Açu (blue line) and Itajaí-Mirim (red line) estuaries (B) during spring tide on August 26, 2003. Hourly variations of water level (C) and volume transport $\left(\mathrm{m}^{3} \mathrm{~s}^{-1}\right)$ across the Itajaí-Açu (blue line) and Itajaí-Mirim (red line) (D) estuaries during neap tide on September 02, 2003. Negative values correspond to the ebb and positive values correspond to the flood.

below $4 \mathrm{~m}$. In the \#M cross-sections the ebb current occurred during the first four hours of the campaign with values of approximately $-0.6 \mathrm{~m} \mathrm{~s}^{-1}$ near the surface that decreased with depth. The current velocity data indicated a reversal pattern of current during most of the campaign.

The salinity at \#A was more stratified throughout the campaign with an isohaline of $30 \mathrm{~g} \mathrm{~kg}^{-1}$ before L.W. and a salinity of less than $10 \mathrm{~g} \mathrm{~kg}^{-1}$ on the surface. The mixture layer was $2 \mathrm{~m}$ thick with a gradient of 10 to $25 \mathrm{~g} \mathrm{~kg}^{-1}$. The bottom layer $(6 \mathrm{~m})$ had a homogenous salinity of $30 \mathrm{~g} \mathrm{~kg}^{-1}$. At \#M, the salinity was more stratified throughout this period. The mixed layer had a thickness of $2.5 \mathrm{~m}$ with a gradient of 10 to $25 \mathrm{~g} \mathrm{~kg}^{-1}$.

\section{Time Averaged Estuarine Structure}

The average temporal profiles of current velocity and salinity during the spring tide campaign are presented in Figure $5 \mathrm{a}$. The current velocity at \#A was residual in the ebb direction with a maximum value of $-0.10 \mathrm{~m} \mathrm{~s}^{-1}$. The salinity profile presented a small vertical gradient that varied from $23 \mathrm{~g} \mathrm{~kg}^{-1}$ at the surface to $25 \mathrm{~g} \mathrm{~kg}^{-1}$ at the bottom. In addition, the current at \#M only presented residual velocity towards the ebb with a maximum value of $-0.13 \mathrm{~m} \mathrm{~s}^{-1}$. Furthermore, the salinity vertical gradient profile at \#M was greater than at \#A (16 g kg-1 at the surface and $22 \mathrm{~g} \mathrm{~kg}^{-1}$ at the bottom).
The average temporal current velocity and salinity profiles along the neap tide campaign are presented in Figure $5 \mathrm{~b}$. The current velocity at \#A was residual in the ebb direction with a maximum value of $-0.27 \mathrm{~m} \mathrm{~s}^{-1}$. The salinity profile was higher and varied from $8 \mathrm{~g} \mathrm{~kg}^{-1}$ at the surface to $29 \mathrm{~g} \mathrm{~kg}^{-1}$ at the bottom. At \#M, the current only exhibited residual velocity towards the ebb with a maximum value of $-0.16 \mathrm{~m} \mathrm{~s}^{-1}$. The salinity vertical gradient profile was pronounced, with a salinity of $8 \mathrm{~g} \mathrm{~kg}^{-1}$ at surface and $25 \mathrm{~g} \mathrm{~kg}^{-1}$ at the bottom.

\section{Vertical MiXING AND SYSTEM CLASSIFICATION}

The layer Richardson number was lower than two during all of the spring tide campaign (Fig. 6A), except for some periods around low and high water, indicating low vertical stability in the water column at \# $A$ and \#M. In the neap tide campaign at \#A, the water column tends to be stable $\left(R i_{L}>20\right)$ for the most of the tidal cycle (Fig. 6B), decreasing in stability near the first low water event. At \#M, the layer Richardson alternated between weak $\left(\mathrm{Ri}_{L}<20\right)$ and strong $\left(\mathrm{Ri}_{L}>\right.$ 20) stability conditions during the neap tide cycle, and the stratification increasing on the last low and high water events.

The values on the Stratification-circulation Diagram (Fig. 7A) classify the Itajaí-Açu as vertically homogeneous (Type 1a) and the Itajaí-Mirim 

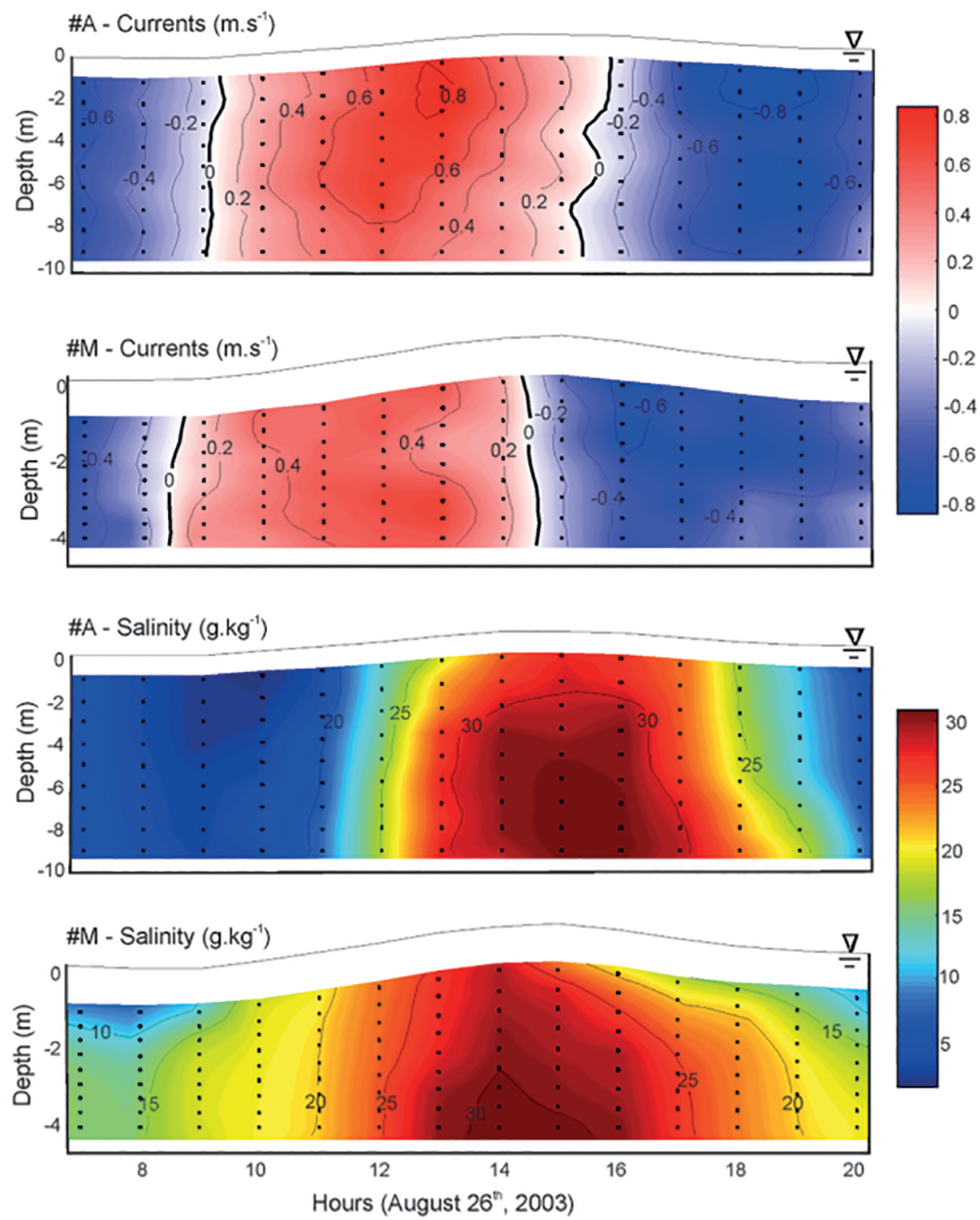

Figure 3. Isopleths of $\mathrm{u}$-velocity components $\left(\mathrm{m} \mathrm{s}^{-1}\right)$ and salinity $\left(\mathrm{g} \mathrm{kg}^{-1}\right)$ during the spring tide campaign on August 26, 2003 at the Itajaí-Açu and Itajaí-Mirim cross-sections. Positive and negative values indicate flood and ebb currents, respectively.

as highly stratified (Type $1 \mathrm{~b}$ ) during the spring tide conditions. In addition, the Itajaí-Açu and Itajaí-Mirim were both classified as salt wedges during neap conditions (Type 4). Geyer and MacCready (2014) parametric space (Fig. 7B) classifies the Itajaí-Açu as strongly stratified. The Itajaí-Mirim was classified as strongly stratified and also cross into the partially mixed classification during spring conditions.

\section{Advective SAlt tRANSPORT}

The numerical values that correspond to the decomposition of advective salt transport per unit width of the \#A and \#M cross-sections during the spring and neap tides are listed in Table 1. During the spring tide campaign, salt transport in \#A was dominantly driven by advective river discharge. Advective river discharge is dispersive transport that results from the correlation between the tide and advective transport generated by Stokes drift, and the resulting total transport estuary below. In \#M, salt transport was dominated by terms that corresponded to advective transport by river discharge and dispersive transport due to tidal correlation with the total transport estuary below. 

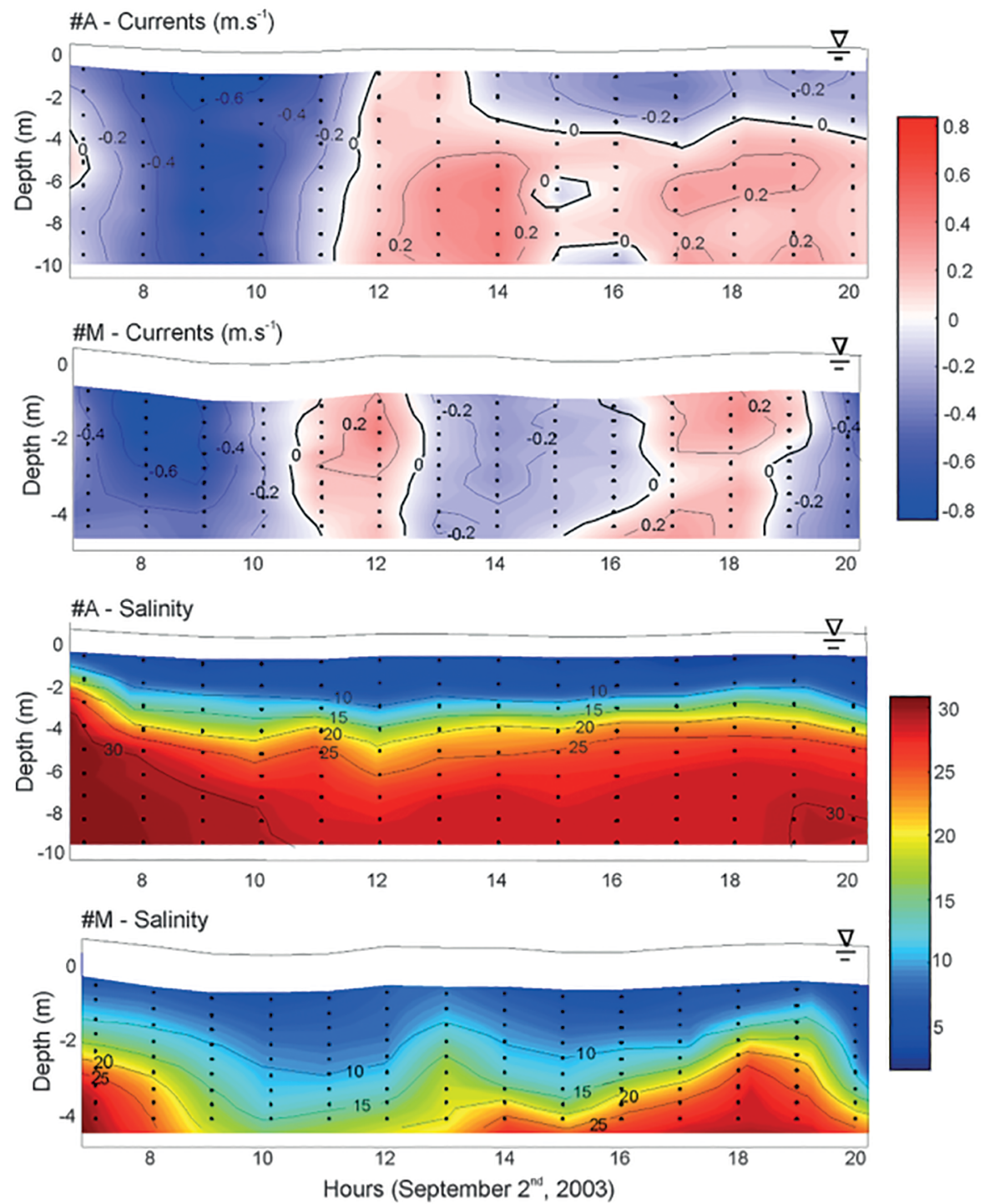

Figure 4. Isopleths of $\mathrm{u}$-velocity component $\left(\mathrm{m} \mathrm{s}^{-1}\right)$ and salinity $\left(\mathrm{g} \mathrm{kg}^{-1}\right)$ during the neap tide campaign on September 02, 2003 at the Itajaí-Açu and Itajaí-Mirim cross-sections. Positive and negative values indicate flood and ebb currents, respectively.

In the neap tide campaign, the dominant terms in \#A were generated by advective river discharge and dispersive transport due to gravitational circulation. In \#M, the transport of salt was dominated by the advective transport term that was generated by river discharge. Among the estuaries and campaign conditions, the total transport of salt was below the estuary.

\section{DISCUSSION}

Estuaries present remarkable temporal and spatial variability (Jay, 2010), which makes comparisons between systems difficult. In the present case, we are comparing a smaller tributary estuary to its main system. One important consideration is that the latter furnishes the sea-side boundary conditions to the former. The systems share the same tidal regime and are under the same climate, differing especially in their drainage basin sizes and in their geometry (Table 2). The \#M's drainage basin is $10 \%$ of the size of \#A's basin, which is reflected in the equivalent freshwater inflow. \#A's cross-section area is $\sim 5 \mathrm{x}$ larger and its thalweg depth is $\sim 2 \mathrm{x}$ deeper than \#M's.

The Itajaí-Açu River estuary is dominated by river discharge, which significantly influences the current regime and salt distribution (Schettini, 2002a). 
(A)

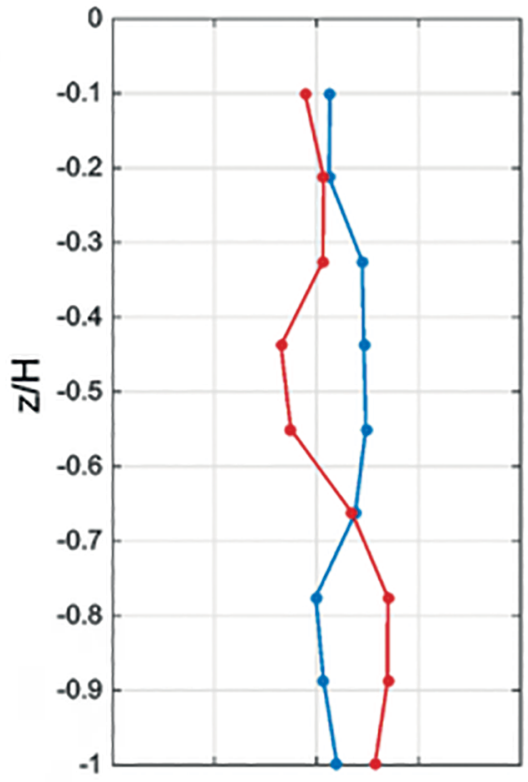

(B)

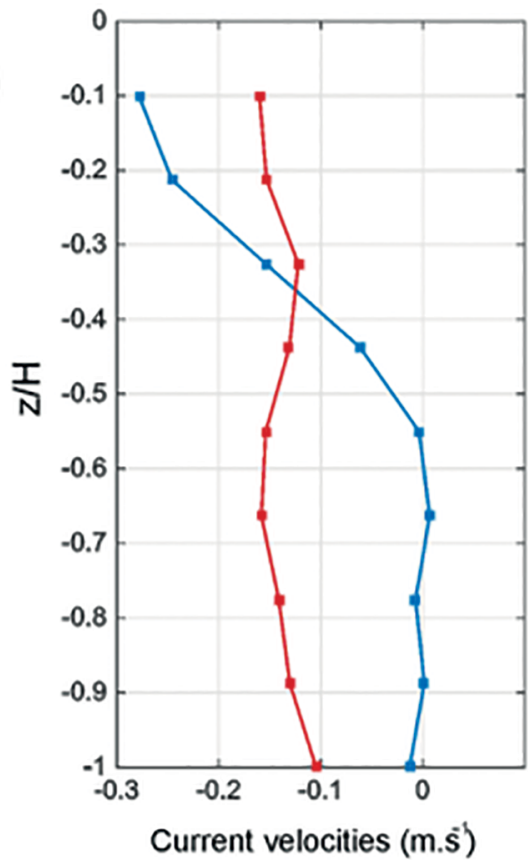

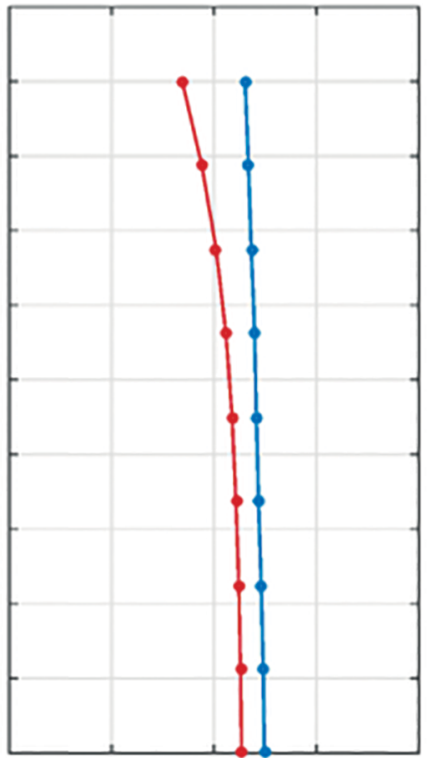

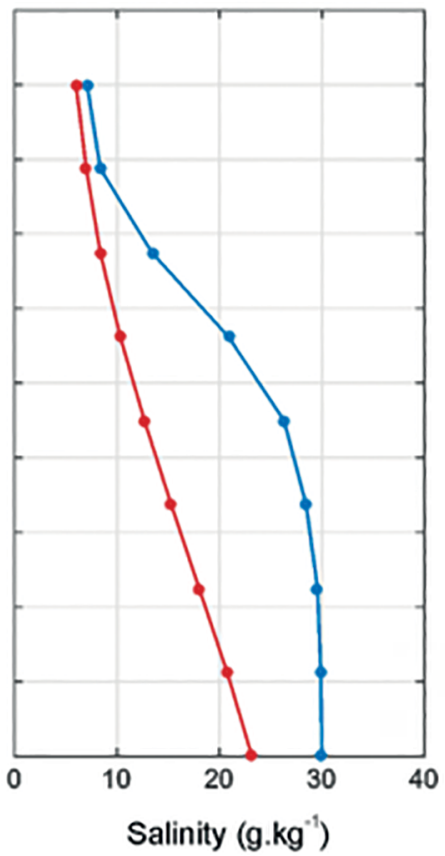

Figure 5. Time-averaged vertical profiles of current velocities $\left(\mathrm{m} \mathrm{s}^{-1}\right)$ and salinity $\left(\mathrm{g} \mathrm{kg}^{-1}\right)$ for spring $(\mathrm{A})$ and neap (B) tides at the Itajaí-Açu (blue line) and Itajaí-Mirim cross-sections (red line).

The flow ratio, or the ratio between the freshwater volume, integrated for a half-tide period to the tidal prism (Dyer, 1974), is $>1$. This results in stronger ebb currents, by mass conservation, and mixing (Schettini et al., 2006). This behavior was not obvious from the present results, which can be understood by the reduced river flow when compared with the long-term mean value. Both systems displayed nearly symmetrical current amplitude during the spring tide, however during neap tide the currents showed a more complex pattern due to the effects of the quarter-diurnal tidal components. Therefore, we can 

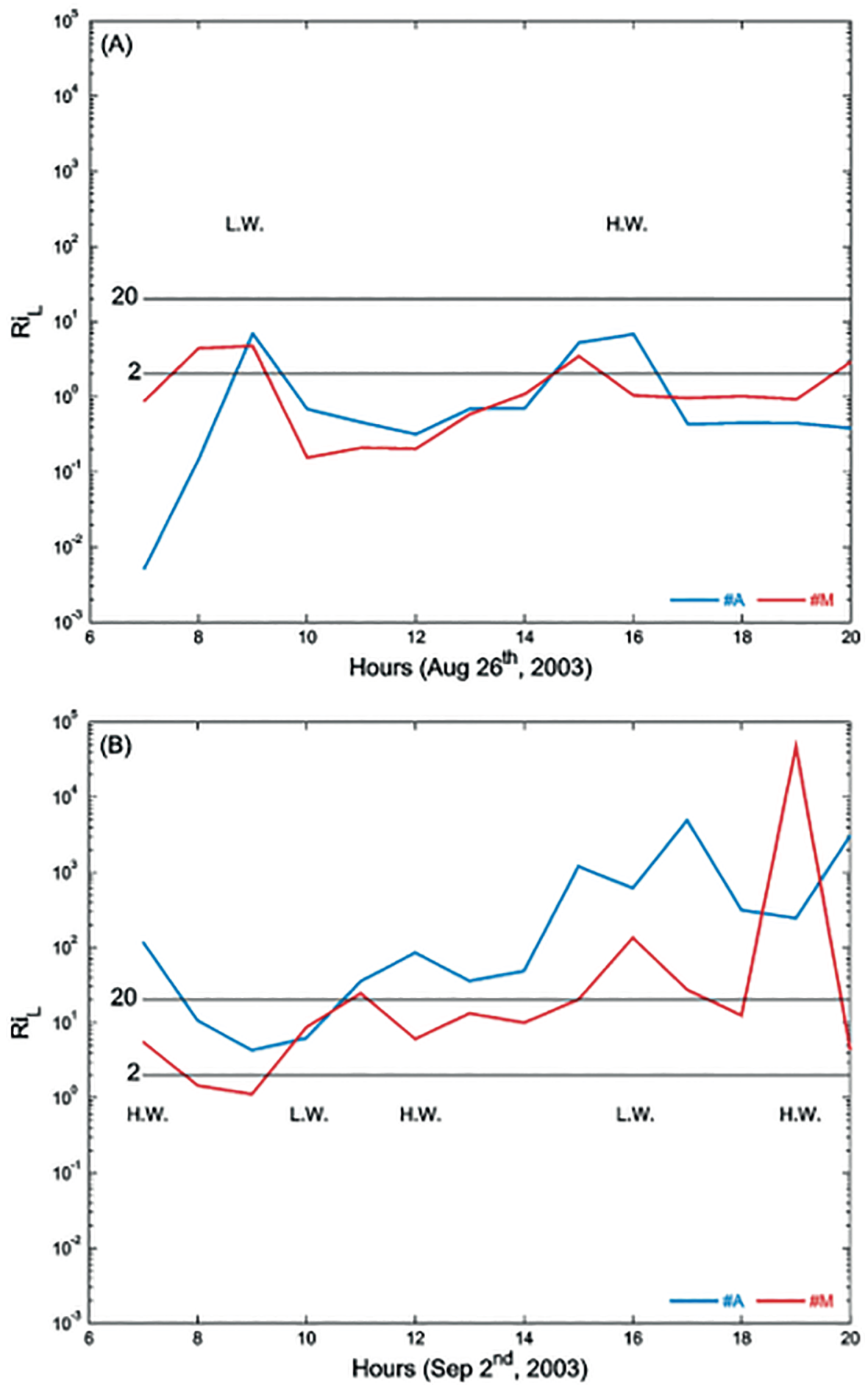

Figure 6. Time variation of the layer Richardson number (RiL) for spring (A) and neap (B) tides at Itajaí-Açu (blue line) and Itajaí-Mirim crosssections (red line). H.W. and L.W. indicates high and low tide.

expected a mixing energy decrease caused by the reduced tidal range, and also from the increase in slack tide periods, enhancing the buoyancy effect (e.g. Simpson et al., 2005; Geyer and MacCready, 2014).
The vertical and temporal velocity and salinity distributions in both cross-sections during spring tide conditions were different from the flood values, which were higher in Section \#A. The occurrence 
(A)

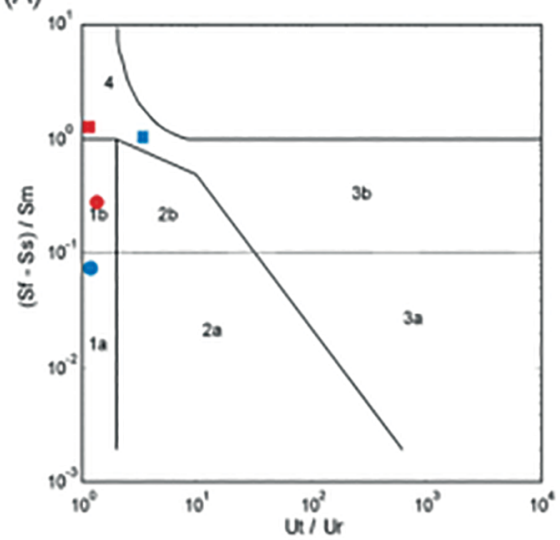

(B)

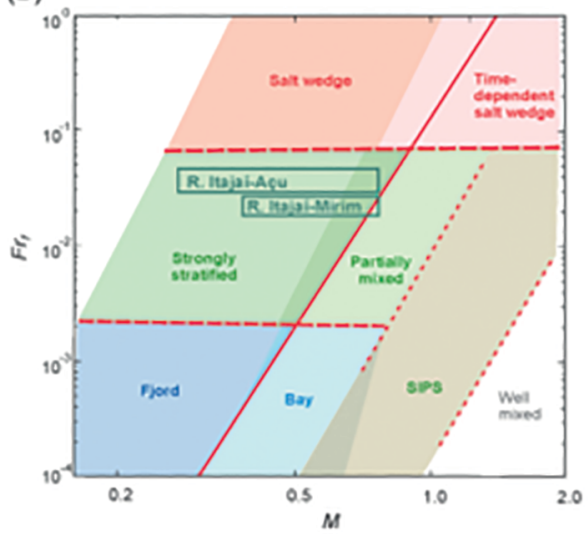

Figure 7. Classification diagrams. (A) Hansen \& Rattray (1966). The blue and red figures represent the Itajaí-Açu and Itajaí-Mirim estuaries, respectively. The circles represent the spring tide and the squares represent the neap tide. (B) Geyer and MacCready (2014). The rectangles (green) represent the Itajaí-Açu and Itajaí-Mirim estuaries.

Table 1. Terms from the advective transport of salt during the semidiurnal spring (August 26, 2003) and neap (September 02, 2003) tidal cycle at the \#A and \#M cross-sections. Values are presented in $\mathrm{kg} \mathrm{m}^{-1} \mathrm{~s}^{-1}$

\begin{tabular}{lcccc}
\hline & \multicolumn{2}{c}{ Spring tide } & \multicolumn{2}{c}{ Neap tide } \\
\hline TERMS & Itajaí-Açu & Itajaí-Mirim & Itajaí-Açu & Itajaí-Mirim \\
\hline 1-Fluvial discharge & $\mathbf{- 1 . 7 4}$ & $\mathbf{- 0 . 7 8}$ & $\mathbf{- 1 . 6 8}$ & $-\mathbf{0 . 8 0}$ \\
2-Stokes drift & 0.15 & 0.00 & 0.03 & 0.00 \\
3-Tidal correlation & $\mathbf{0 . 3 6}$ & $\mathbf{0 . 2 2}$ & -0.05 & 0.02 \\
4-Gravitational circulation & 0.00 & 0.02 & 0.87 & 0.02 \\
5-Tidal pumping & 0.00 & 0.00 & 0.04 & 0.00 \\
6-Tidal shear & 0.00 & 0.00 & 0.00 & 0.00 \\
7-Wind fluctuation & -0.01 & -0.01 & -0.01 & -0.00 \\
Total transport & $\mathbf{- 1 . 2 3}$ & $\mathbf{- 0 . 5 6}$ & $\mathbf{- 0 . 8 0}$ & $\mathbf{- 0 . 7 4}$
\end{tabular}

Table 2. Summary of main characteristics of the Itajaí-Açu and Itajaí-Mirim estuaries. The river flow values are for the survey period.

\begin{tabular}{lcc}
\hline & Itajaí-Açu & Itajaí-Mirim \\
\hline Drainage basin area $\left(\mathrm{km}^{2}\right)$ & 14,100 & 1,400 \\
River flow $\left(\mathrm{m}^{3} / \mathrm{s}\right)$ & 63.6 & 5.7 \\
Cross-section area $\left(\mathrm{m}^{2}\right)$ & 1,200 & 230 \\
Thalweg depth $(\mathrm{m})$ & 8 & 4 \\
\hline
\end{tabular}

intervals for the peak flood and ebb tides between the two estuaries were one and two hours, respectively, and the events occurred first in \#M. The variation of salinity was higher in cross-section \#M and was stratified in the water column in two phases. However, in \#A, the vertical distribution of salinity was comparatively less stratified. In both cross-sections, the maximum values were observed before to high tide slack water.

The changes between spring and neap tides are reflected in the situation in the estuaries classification using Hansen and Rattray's (1966) circulation-stratification diagram (Figure 7A). During spring tide \#A was well-mixed (type 1a) and \#B was highly stratified (type 16 ) and in both cases the parameter was 1 , indicating that the salt transport is mainly due to turbulent diffusion (Miranda et al., 2012; Geyer and MacCready, 2014). During neap tide, both estuaries were classified as salt-wedge (type 4), when salt transport is mainly due to advection. This situation change was already reported for the Itajaí-Açu estuary (Schettini, 2002a), and it seems that the Itajaí-Mirim estuary 
displays fewer spring-neap tide changes than the Itajaí-Açu.

The stratification parameter can vary widely from one point to another in the estuary, which contributes to this migration. In addition, some systems will occupy different positions in the diagram as the stratification and circulation parameters change from spring to neap, from dry to wet seasons, and from year to year (Valle-Levinson, 2010). Geyer and MacCready (2014) propose an alternative way to classify estuaries. In their classification, the estuaries are represented by areas (rectangles) in a parameter space, indicating the approximate influence of the variation of the spring-neap tides, variation of the river flow and mixing. In this parameter space (Figure 7B), both estuaries were in the 'strongly stratified' area. While the Hansen and Rattray scheme gives us an instantaneous portrait of the estuarine dynamics in a given moment, the Geyer and MacCready scheme gives us a long-term assessment of the dominant estuarine structure.

The salt transport mechanism during spring tide was similar in \#A and \#M, dominated by fluvial discharge seawards and has the main dispersive mechanism of the tidal correlation landwards. The transport was nearly the same in both estuaries considering the depth in \#A is $\sim 2 x$ of the \#M. This pattern changed in the neap tide. The main transport mechanism is still the fluvial discharge in both estuaries, with similar values of spring tide, however, tidal correlation lost its importance. The main dispersive mechanism shifted to gravitational circulation but only in \#A. There was no relevant dispersive mechanism in $\# \mathrm{M}$, and the total salt transport values now are equivalent. However, taking the depth into account, it is much greater in \#M. These findings are potentially related to the differences in bottom topography between the two estuaries. The bottom topography potentially differentiates tidal wave propagation in the channel and mass transport. The dispersive terms of salt transport were not representative of the Itajaí-Mirim estuary during the neap tide campaign. Regarding the Itajaí-Açu estuary during neap tide conditions, the transport generated by gravitational circulation was the dominant dispersive term. This finding can be observed from the vertical-temporal profile of the current velocity over 13 hours of the campaign.

\section{CONCLUSIONS}

As a general conclusion, we can state that the Itajaí-Mirim estuary behaves quite similarly to the
Itajaí-Açu estuary. This is understood as they share the same tidal regime and hydrological climate, and also as the latter furnishes the lower boundary conditions to the former. However, as their geometries differ (Itajaí-Açu/Itajaí-Mirim cross-sectional area is $\sim 5$ and the thalweg depth is $\sim 2$ ), and the Itajaí-Mirim is dynamically shallower, this will produces differences in the flow regime. The main differences and similarities between both estuaries are: i) the flood-ebb currents are greatest in the Itajaí-Açu and asymmetrical in the Itajaí-Mirim, but in both estuaries the ebb currents are more intense than the flood; ii) the residual currents were downstream for both cross-sections and tidal cycles; iii) the water column was stratified during the neap tide and homogenized conditions prevailed over the spring tide at both cross-section; iv) during the spring tide, the bottom turbulence may become effective $\left(R i_{L}<20\right)$ and at the end of the neap tide, the turbulent mixing was suppressed $\left(R i_{L}>20\right)$; $v)$ the estuary classifications were different for spring tide conditions, with well mixed (type 1a) for ItajaíAçu and well mixed (type 1b) for Itajaí-Mirim, and were salt wedge for both estuaries on neap tide; vi) in both cross-sections the predominant downstream transport of salt was dominated by river discharge, associated with dispersive correlation tide (both systems) and Stokes transport (only in Itajaí-Açu) during spring tide conditions. Over neap tide, the river discharge was dominant downstream transport of salt and the gravitational circulation was dominant upstream only for the Itajaí-Açu estuary.

\section{ACKNOWLEDGMENTS}

We wish to express our thanks to Lourival, Nane, Rodrigo, Fábio, Liana and Valdenir for assisting with the hydrological data collection. Our thanks are also due to Professor Luis B. de Miranda for his comments and suggestions. CNPq grants 306217/2007-4.

\section{AUTHOR CONTRIBUTIONS}

M.A.A.C: Conceptualization, Methodology, Validation, Formal analysis, Investigation, Data curation, Writing - review \& editing.

C.A.F.S: Conceptualization, Methodology, Validation, Investigation, Writing - review \& editing, Resources, Supervision, Funding acquisition. 


\section{REFERENCES}

ARAÚJO, S., HAYMUSSI, H., REIS, F. \& SILVA, F. 2006. Caracterização climatológica do município de Penha, SC. In: BRAVO, J. \& MARENZI, W. (ed.). Bases ecológicas para um desenvolvimento sustentável: estudos de caso em Penha, SC. Itajaí: Editora da UNIVALI.

BARRETO, G. \& SCHETTINI, C. 2014. Papel da maré e da descarga fluvial na circulação do estuário do Rio Araranguá. Brazilian Journal of Water Resources, 19(3), 7-17.

BOWDEN, K. 1963. The mixing processes in a tidal estuary. Journal of Air and Water Pollution, 7, 343-356.

CAMERON, W. M. \& PRITCHARD, D. 1963. Estuaries. In: HILL, M. N. (ed.). The sea. New York: Interscience, pp. 306-332.

D'AQUINO, C. A., BARRETO, G. A., ANDRADE, N. \& SCHETTINI, C. 2011. Caracterização oceanográfica e do transporte de sedimentos em suspensão no estuário do rio Mampituba, SC. Revista Brasileira de Geofísica, 29(2), 217-230.

D'AQUINO, C. A., PEREIRA FILHO, J. \& SCHETTINI, C. A. F. 2010. Fluvial modulation of hydrodynamics and salt transport in a highly stratified estuary. Brazilian Journal of Oceanography, 58(2), 165-175.

D'AQUINO, C. A., SILVA, L. F., COUCEIRO, M., PEREIRA, M. \& SCHETTINI, C. 2011. Transporte de sal e hidrodinâmica do estuário do rio Tubarão SC, Brasil. Revista Brasileira de Recursos Hídricos, 16(3), 113-125.

DIONNE, J. 1963. Towards a more adequate definition of the St. Lawrence estuary. Zeitschrift fuer Geomorphologie, 7(1), 36-44.

DÖBEREINER, C. 1986. Sedimentação no estuário do Rio Itajaí-açu. In: Congresso Latino Americano de Hidráulica. São Paulo: AIPH, pp. 68-79.

DYER, K. 1974. The salt balance in stratified estuaries. Estuarine and Coastal Marine Science, 2(3), 273-281.

DYER, K. 1997. Estuaries: a physical introduction. $2^{\text {nd }}$ ed. New York: John Wiley \& Sons.

DYER, K. R. \& NEW, A. L. 1986. Intermittency in estuarine mixing. In: WOLFE, D. (ed.). Estuarine variability. Florida: Academic Press, pp. 321-339.

FISCHER, H. B. 1976. Mixing and dispersion in estuaries. Annual Review of Fluid Mechanics, 8, 107-133.

FRANKLIN-SILVA, L. \& SCHETTINI, C. A. F. 2003. Avaliação da dinâmica lateral e dos mecanismos de transporte no estuário do rio Camboriú. Notas Técnicas FACIMAR, 7, 97-108.

GEYER, W. R. \& MACCREADY, P. 2014. The estuarine circulation. Annual Review of Fluid Mechanics, 46, 175-197.

GLAPAN. 1986. Atlas de Santa Catarina. Rio de Janeiro: Aerofoto Cruzeiro.

HANSEN, D. \& RATTRAY JUNIOR, M. 1966. New dimensions on estuarine classification. Limnology and Oceanography, 11(3), 319-326.

HUNKINS, K. 1981. Salt dispersion in the Hudson estuary. Journal of Physical Oceanography, 11(5), 729-738.
JAY, D. A. 2010. Estuarine variability. In: VALLE-LEVINSON, A (ed.). Contemporary issues in estuarine physics. New York: Cambridge University Press, pp. 62-99.

KJERFVE, B. 1986. Circulation and salt flux in a well mixed estuary. In: VAN DE KREEK, J. (ed.). Physics of shallow estuaries and bays. New York: Springer, pp. 22-29.

KÖPPEN, W. \& GEIGER, R. 1928. Klimate der Erde. Gotha: Verlag Justus Perthes.

MIRANDA, L. B., CASTRO, B. M. \& KJERFVE, B. 2012. Princípios de oceanografia física de estuários. $2^{\text {nd }}$ ed. São Paulo: Editora da USP.

PONÇANO, W. \& GIMENEZ, A. 1987. Reconhecimento sedimentólogico do estuário do Itajaí-Açu. Revista Brasileira de Geociências, 17(1), 33-41.

POND, S. \& PICKARD, G. L. 1983. Introductory dynamical oceanography. $2^{\text {nd }}$ ed. New York: Pergamon.

SCHETTINI, C. A. 2002a. Caracterização física do estuário do rio Itajaí-Açu. Revista Brasileira de Recursos Hídricos, (7), pp. 123-142.

SCHETTINI, C. A. 2002b. Near bed sediment transport in the Itajaí-Açu River Estuary, southern Brazil. In: WINTERWERP, J. \& KRANENBURG, C. (ed.). Fine sediment dynamics in the marine environment. New York: Elsevier, pp. 499-512.

SCHETTINI, C. A. \& CARVALHO, J. 1998. Hidrodinâmica e distribuição de sólidos em suspensão no estuário do rio Itajaí-Açu. Notas Técnicas FACIMAR, 2(1), 131-140.

SCHETTINI, C. A. \& CARVALHO, J. 1999. Caracterização hidrodinâmica do estuário do rio Cubatão, Joinville. Notas Técnicas FACIMAR, 3(1), 87-97.

SCHETTINI, C. A., CARVALHO, J. \& JABOR, P. 1996. Comparative hydrology and suspended matter distribution of four estuaries in Santa Catarina State-Southern Brazil. In: Proceedings of Workshop on Comparative Studies of Temperate Coast Estuaries, Bahia Blanca, pp. 29-32.

SCHETTINI, C. A., RICKLEFS, K., TRUCCOLO, E. C. \& GOLBIG, V. 2006. Synoptic hydrography of a highly stratified estuary. Ocean Dynamics, 56(3-4), 308-319.

SCHETTINI, C. A. \& TOLDO JUNIOR, E. E. 2006. Fine sediment transport modes in the Itajaí-Açu estuary, Southern Brazil. Journal of Coastal Research, 39(SI), 515-519.

SIEGLE, E., SCHETTINI, C. A., KLEIN, A. H. F. \& TOLDO JUNIOR, E. E. 2009. Hydrodynamics and suspended sediment transport in the Camboriú estuary-Brazil: pre-jetty conditions. Brazilian Journal of Oceanography, 57(2), 123-135.

SIMPSON, J. H., WILLIAMS, E., BRASSEUR, L. H. \& BRUBAKER, J. M. 2005. The impact of tidal straining on the cycle of turbulence in a partially stratified estuary. Continental Shelf Research, 25(1), 51-64.

VALLE-LEVISION, A. 2010. Contemporary issues in estuarine physics. New York: Cambridge University Press.

VALLE-LEVINSON, A. \& SCHETTINI, C. A. 2016. Fortnighly switching or residual flow drivers in a tropical semiarid estuary. Estuarine, Coastal and Shelf Science, 169, 46-55. 